\title{
Prediction of morbidity after gastrectomy for gastric adenocarcinoma using logistic regression analysis
} Luis F Oñate-Ocaña*1, Mauricio Becker ${ }^{1}$, Vincenzo Aiello-Crocifoglio ${ }^{1}$, Rocío Brom-Valladares ${ }^{2}$, José F Carrillo ${ }^{3}$, Francisco Ochoa-Carrillo ${ }^{3}$ and Arturo Beltrán-Ortega ${ }^{3}$

\author{
Address: ${ }^{1}$ Gastroenterology Department, Instituto Nacional de Cancerología, México, ${ }^{2}$ Computed Tomography, Ultrasound and Magnetic \\ Resonance Department, Instituto Nacional de Cancerología, México and ³ Surgery Division, Instituto Nacional de Cancerología, México \\ Email: Luis F Oñate-Ocaña* - lonate@gmail.com \\ * Corresponding author
}

from 24 $4^{\text {th }}$ Annual Meeting of the National Cancer Institute of Mexico

Mexico City, Mexico. 14-17 February 2007

Published: 5 February 2007

BMC Cancer 2007, 7(Suppl I):A35 doi:10.1 186/147I-2407-7-SI-A35

This article is available from: http://www.biomedcentral.com//47I-2407/7/SI/A35

(C) 2007 Oñate-Ocaña et al; licensee BioMed Central Ltd.

\section{Background}

Surgical morbidity after gastrectomy remains high in some institutions. In a recent report, we reported a simple method to predict the probability of complications after gastrectomy. However, we did not stratify the severity of surgical morbidity. Therefore, the aim of this study was increase the sample size, to define the major determinants of surgical morbidity and to develop a computer model to predict the probability of complications after gastrectomy for GC.

\section{Methods}

A retrospective cohort of patients with GC who underwent gastrectomy in a 18 -year period was studied. Analysis of those factors associated to surgical morbidity and mortality were performed using logistic regression methodology.

\section{Results}

A total of 331 patients were included, 161 females and 170 males (mean age 56.5 years, SD13.1). Surgical morbidity was recorded in 126 (38\%) patients. Surgical morbidity requiring a medical or surgical intervention was reported in 81 cases $(24.4 \%)$, including 21 cases $(6.3 \%)$ of operative mortality. Serum albumin, age more than 40 years, male gender, total gastrectomy and operative bleeding were significant determinants of surgical morbidity. Estimators of this model are shown in Table $1(\mathrm{p}=$ 0.00001 ). Total gastrectomy, male gender, serum albumin and surgical bleeding were determinants of severe complications. ( $\mathrm{p}=0.0001)$. Total gastrectomy, surgical bleeding and the interaction of lymphocyte count by serum albumin are significant predictors of surgical mortality $(\mathrm{p}=$ 0.0001).

\section{Conclusion}

The event of surgical mortality should be regarded as a complex phenomenon associated with the interaction of various events. We are proposing to use a simple computer program based on multivariate analysis to calculate the probability of the event of surgical morbidity or mortality. This method should be tested in other institutions to assess its performance before it can be used in the decision-making process. 
Table I: Multivariate analisis of factors associated to the event of surgical morbidity $(p=0.0000 \mathrm{I})$

\begin{tabular}{|c|c|c|c|c|c|}
\hline Factor & $\beta$ & S.E. & $p$ & $\beta(\exp )$ & $95 \% \mathrm{Cl}$ \\
\hline Serum Albumin & & & 0.034 & & \\
\hline $2.9 \mathrm{~g} / \mathrm{dL}$ or less & 0.772 & 0.307 & 0.012 & 2.165 & $1.19-3.95$ \\
\hline 3 to $3.49 \mathrm{~g} / \mathrm{dL}$ & 0.063 & 0.309 & 0.84 & 1.065 & $0.58-1.95$ \\
\hline $3.5 \mathrm{~g} / \mathrm{dL}$ or more & - & - & - & I & - \\
\hline \multicolumn{6}{|l|}{ Gastrectomy } \\
\hline subtotal & - & - & - & 1 & - \\
\hline total & 0.956 & 0.255 & 0.0001 & 2.6 & $1.58-4.29$ \\
\hline \multicolumn{6}{|l|}{ Age } \\
\hline 39 or less & - & - & - & I & - \\
\hline more than 40 & 0.847 & 0.394 & 0.032 & 2.333 & $1.07-5.05$ \\
\hline \multicolumn{6}{|l|}{ Gender } \\
\hline Female & - & - & - & I & - \\
\hline Male & 0.447 & 0.245 & 0.069 & 1.563 & $0.966-2.53$ \\
\hline $\begin{array}{l}\text { Surgical bleeding } \\
(\mathrm{ml})\end{array}$ & 0.001 & 0.0001 & 0.031 & 1.001 & $1-1.001$ \\
\hline
\end{tabular}

$\beta=;$ S.E. = standard error; $\mathrm{P}=$ probability value of the odds ratio; $\beta(\exp )=$ beta exponent or odds ratio; $\mathrm{Cl}=$ confidence interval

Publish with Bio Med Central and every scientist can read your work free of charge

"BioMed Central will be the most significant development for disseminating the results of biomedical research in our lifetime. "

Sir Paul Nurse, Cancer Research UK

Your research papers will be:

- available free of charge to the entire biomedical community

- peer reviewed and published immediately upon acceptance

- cited in PubMed and archived on PubMed Central

- yours - you keep the copyright 